\title{
Exploring Gender Disparity In U.S. Based Venture Capital Firms
}

David A. Blum, DBA, Northcentral University, USA

\begin{abstract}
Female partners and directors are underrepresented in the U.S. venture capital industry. Approximately 10\% of independent venture capitalists are female. This gender disparity can have a negative affect on entrepreneurism and economic activity. The result of having few women partners and directors in venture capital is male entrepreneurs often do not market and or produce products sensitive to female needs in the marketplace. The gender disparity is caused in part by limited mentoring opportunities, few female role models, lack of executive management experience, and female exclusion from primary niche networks. Two gaps in literature are addressed in this paper. First, an exploration of the factors contributing to gender disparity among directors and partners at independent venture capital firms in the United States. Second, this paper contributes to the dearth of the underexplored phenomenon. The research question guiding this study was what are the factors for the gender disparity among directors and partners at independent venture capital firms in the United States. This paper provides IVC directors and managers with the four factors contributing to the underrepresentation of females in venture capital. This paper also provides implications of not having greater female participation, and recommendations to hire qualified female partners and directors at independent venture capital firms in the United States.
\end{abstract}

Keywords: Independent Venture Capital; Gender Disparity; Partners; Directors

\section{INTRODUCTION}

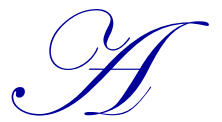

pproximately $10 \%$ of independent venture capitalists (IVC) directors and partners in the United States are female (Brush, Carter, Gatewood, Greene, \& Hart, 2004; Gatewood, Brush, Carter, Greene, \& Hart, 2009; Lietz, 2012; Merino, 2013). The phenomenon is not new. Women representation in the early $1990 \mathrm{~s}$ was at approximately $11 \%$ (Gatewood et al., 2009). Scant reasons exist in the extant literature addressing the underexplored phenomenon. To address gender disparity in the IVC industry, I conducted a study in July and August 2014 interviewing 20 partners and directors in the United States. The research question guiding the study was what are the factors for gender disparity among directors and partners at independent venture capital firms in the United States. This paper provides an overview of the IVC industry, gender disparity, and women in venture capital. I outlined the study parameters, factors contributing to gender disparity, implications, and recommendations to industry.

\section{LITERATURE REVIEW}

\section{Venture Capital Overview}

IVCs invest in nascent market scalable, high growth, high-risk technology-based firms. IVCs stimulate innovation, job creation, technology improvements, enhancement of international competitiveness, and economic growth (Li \& Zahra, 2012). IVC firms provide equity funding, impart advice and expertise to portfolio firms, and create opportunities for high return on investment for investors (Jackson, Bates, \& Bradford, 2012; Olsson, Frydenberg, Jakobsen, \& Jessen, 2010; Schertler \& Tykvova, 2011; Zhang, Aksu, \& Wang, 2012). 
IVCs locate investment opportunities from established network contacts, evaluate business plans, negotiate valuation and terms of investment, offer strategic advice, and exit from the portfolio firm with anticipated high returns on investment (Blum 2014; Dotzler, 2001). Once the IVC has decided to work and fund a portfolio firm after conducting more than 50 hours of due diligence; the IVC continues to spend approximately 10 hours per month on coaching and advising management, approximately six hours per month recruiting key personnel, and approximately six hours per month securing additional financing (Smart, Payne, \& Yuzaki, 2000).

Venture capital firms are usually under 10 people, are male dominated and invest in portfolio firms within specific geographical areas and technologies, and are very difficult for the typical entrepreneur to access (Brush et al., 2004; Gatewood et al., 2009). IVCs tend to enter the industry upon urging from friends and mentors (Smart et al., 2000). Individuals with entrepreneurial, technical, and finance backgrounds tend to be attracted to venture capital (Smart et al., 2000). Being hired by a venture capital firm often requires having personal contacts usually through formal and informal networks (Smart et al., 2000). IVCs generally work in the industry for financial enhancement and in building new organizations (Smart et al., 2000).

Individuals come to venture capital from different career tracks such as apprentice, seasoned executives, and retired high net worth individuals. The apprentice comes directly from graduate and or technical schools such as Stanford, Harvard, Caltech, MIT, or Wharton after earning degrees in economics or finance (Brush et al., 2004). The apprentice's entry into venture capital is usually as an analyst or principal. Venture capital firms hire seasoned management executives from operational areas such as marketing, sales, or technology. Executives working in operations enter venture capital after many years in industry. Often these former executives bestow their knowledge, experiences, and skills in helping entrepreneurs contribute to the economy. The retired group is individuals over the age of 40 who held senior leadership positions and became wealthy from a successful exit. Often the retired group received venture capital funding to start their businesses. The retired group enters the venture capital industry to fund firms to attain high return on investment and to assist nascent entrepreneurs.

IVCs must possess soft and hard skills. Relevant soft skills encompass recruiting talent, listening, qualitative analysis, and providing mentorship, advice, and coaching (Smart et al., 2000). Hard skills are technical evaluations and analytical and financial data analysis (Smart et al., 2000). Successful IVCs often have the viewpoint of a CEO. Soft and hard skills are not within the domain of a particular gender.

\section{Gender Disparity in Venture Capital}

Fiske, Cuddy, Glick, and Xu (2002) and Spence and Buckner (2000) indicated cultural beliefs in the U.S. attributed men as being more competent than women in business transactions and personal interactions. Research on gender disparity has focused on professional individuals in wide ranging domains such as the legal industry, technology, venture capital, life sciences, B2C, and Fortune 500 boards to name a few (Brush, et al., 2004; Ding, Murray, \& Stuart, 2013; Fernandez-Mateo \& King, 2011; Gorman \& Kmec, 2009; Skaggs, Stainback \& Duncan, 2012). Gender stereotypes and beliefs in venture capital affect equality, bias, and interpersonal relationships (Brush et al., 2004; Ridgeway \& Correll, 2004). Women have been traditionally underrepresented compared to men in science, technology, engineering, and mathematics (STEM) fields, and related start-ups, which are fertile ground for IVC development (Baron \& Markman, 2000). The male dominated venture capital industry values good ideas where investment decisions are more or less perceived to be gender-blind (Brush et al., 2004).

Pre-existing networking relationships provide connection between venture capitalists and entrepreneurs (Brush et al., 2004). Lacking links to venture capitalists, women entrepreneurs have lower probabilities of obtaining venture financing (Brush et al., 2004). Brush et al. posited women believe their networks include both genders. However, men stated they have no women in their networks (Brush et al., 2004). The consequence is women entrepreneurs sometimes believe they have robust connections to the IVC industry, when in reality relevant relationships do not exist (Brush et al., 2004).

IVCs generally work with a set of criteria sometimes known as a mental model used as a template when considering a business idea (Nelson, Maxfield, \& Kolb, 2009). The mental model template is developed over time formed by the IVCs experience, education, networks, known industry preferences, and behavioral patterns (Nelson 
et al., 2009). The mental model is constructed from a hierarchy of order along lines of gender, including notions of venture potential and success in addition to masculine/man and feminine/woman attributes (Nelson et al., 2009). Social business interactions are key to establishing credibility and legitimacy in the IVC industry (Nelson et al., 2009). Table 1 provides a breakdown of gender disparity at leading U.S. based venture capital firms.

Table 1. Leading U.S. based Venture Capital Firms Men and Women Disparity

\begin{tabular}{|c|c|c|c|}
\hline Venture Capital Firm & Men & Women & \% Women \\
\hline Accel & 25 & 1 & $4 \%$ \\
\hline Advantage Capital Partners & 22 & 1 & $4 \%$ \\
\hline Alta & 4 & 1 & $20 \%$ \\
\hline Altos & 3 & 0 & $0 \%$ \\
\hline Andreessen Horowitz & 15 & 5 & $25 \%$ \\
\hline Arborview & 5 & 0 & $0 \%$ \\
\hline Arch Ventures & 17 & 1 & $5 \%$ \\
\hline Argentum & 4 & 0 & $0 \%$ \\
\hline Atlas Ventures & 11 & 0 & $0 \%$ \\
\hline Austin & 11 & 0 & $0 \%$ \\
\hline Azure Capital Partners & 8 & 0 & $0 \%$ \\
\hline Bain Capital Ventures & 17 & 0 & $0 \%$ \\
\hline Battery Ventures & 7 & 1 & $13 \%$ \\
\hline Bessemer & 25 & 0 & $0 \%$ \\
\hline Blue Vine & 5 & 0 & $0 \%$ \\
\hline Bluerun Ventures & 3 & 1 & $33 \%$ \\
\hline Boston Seed Capital & 3 & 0 & $0 \%$ \\
\hline Braemar & 4 & 1 & $20 \%$ \\
\hline Brook Venture Partners & 4 & 0 & $0 \%$ \\
\hline Canaan & 8 & 2 & $20 \%$ \\
\hline Cava Capital & 2 & 1 & $33 \%$ \\
\hline Center for Innovative Technology & 5 & 0 & $0 \%$ \\
\hline Charles River Ventures & 8 & 1 & $11 \%$ \\
\hline Chicago Ventures & 3 & 0 & $0 \%$ \\
\hline Column Group & 10 & 0 & $0 \%$ \\
\hline Connecticut Innovations & 2 & 0 & $0 \%$ \\
\hline Correlation & 3 & 0 & $0 \%$ \\
\hline Crescendo Ventures & 4 & 0 & $0 \%$ \\
\hline Crosslink Capital & 8 & 0 & $0 \%$ \\
\hline CrunchFund & 2 & 0 & $0 \%$ \\
\hline Data Collective & 4 & 0 & $0 \%$ \\
\hline DCM & 9 & 0 & $0 \%$ \\
\hline DeNovo Ventures & 5 & 0 & $0 \%$ \\
\hline DFJ & 15 & 3 & $17 \%$ \\
\hline e.ventures & 4 & 0 & $0 \%$ \\
\hline Edison Ventures & 10 & 1 & $9 \%$ \\
\hline Elm Street & 2 & 0 & $0 \%$ \\
\hline Fairview Capital & 5 & 1 & $17 \%$ \\
\hline Felicis Ventures Mgmt Co & 2 & 1 & $33 \%$ \\
\hline Fenox VC & 4 & 0 & $0 \%$ \\
\hline FF Venture Capital & 4 & 0 & $0 \%$ \\
\hline First Round Capital & 6 & 1 & $14 \%$ \\
\hline Firstmark capital & 15 & 0 & $0 \%$ \\
\hline Floodgate Fund & 1 & 2 & $66 \%$ \\
\hline Fomative Ventures & 3 & 0 & $0 \%$ \\
\hline Foundation Capital & 13 & 0 & $0 \%$ \\
\hline Founder Collective & 6 & 1 & $14 \%$ \\
\hline Foundry Group & 4 & 0 & $0 \%$ \\
\hline FundersClub & 2 & 0 & $0 \%$ \\
\hline General Catalyst & 25 & 0 & $0 \%$ \\
\hline Great Oaks Venture Capital & 3 & 0 & $0 \%$ \\
\hline
\end{tabular}


(Table 1 continued)

\begin{tabular}{|c|c|c|c|}
\hline Venture Capital Firm & Men & Women & \% Women \\
\hline Greycroft Partners & 6 & 1 & $14 \%$ \\
\hline Greylock & 16 & 0 & $0 \%$ \\
\hline Healthbox & 1 & 9 & $90 \%$ \\
\hline Highland Capital Partners & 12 & 0 & $0 \%$ \\
\hline Hummer-Winblad V.P. & 3 & 1 & $25 \%$ \\
\hline IDG Ventures & 3 & 0 & $0 \%$ \\
\hline Ignition Partners & 4 & 0 & $0 \%$ \\
\hline Index Ventures & 5 & 0 & $0 \%$ \\
\hline Industry Ventures & 6 & 0 & $0 \%$ \\
\hline Institutional Venture Partners & 7 & 0 & $0 \%$ \\
\hline Interwest Partners & 9 & 1 & $10 \%$ \\
\hline Kapor Capital & 2 & 1 & $33 \%$ \\
\hline Kearney Venture Partners & 4 & 0 & $0 \%$ \\
\hline Khosla & 10 & 2 & $20 \%$ \\
\hline Kima Ventures & 2 & 0 & $0 \%$ \\
\hline Kleiner Perkins Caufield \& Byers & 25 & 6 & $19 \%$ \\
\hline Launch Capital & 2 & 0 & $0 \%$ \\
\hline Lerer Ventures & 4 & 0 & $0 \%$ \\
\hline Levensohn Venture Partners & 2 & 0 & $0 \%$ \\
\hline Lightbank & 3 & 1 & $25 \%$ \\
\hline Lightspeed & 10 & 0 & $0 \%$ \\
\hline Madrona Venture Group & 9 & 0 & $0 \%$ \\
\hline Matrix Partners & 10 & 0 & $0 \%$ \\
\hline Maveron & 6 & 0 & $0 \%$ \\
\hline Mayfield & 5 & 1 & $17 \%$ \\
\hline MDV & 7 & 2 & $22 \%$ \\
\hline MESA & 7 & 1 & $13 \%$ \\
\hline New Enterprise Associates & 32 & 4 & $11 \%$ \\
\hline New Leaf Partners & 5 & 2 & $29 \%$ \\
\hline Nexit Ventures & 5 & 0 & $0 \%$ \\
\hline Next World Capital & 5 & 0 & $0 \%$ \\
\hline Norwest Venture Partners & 15 & 3 & $17 \%$ \\
\hline Nth Power & 2 & 1 & $33 \%$ \\
\hline O'Reilly AlphaTech Ventures & 2 & 0 & $0 \%$ \\
\hline Oak Investment Partners & 16 & 4 & $20 \%$ \\
\hline Onset Ventures & 8 & 0 & $0 \%$ \\
\hline Open View & 8 & 0 & $0 \%$ \\
\hline Physic Ventures & 3 & 1 & $25 \%$ \\
\hline Pinnacle Ventures & 3 & 0 & $0 \%$ \\
\hline Polaris Partners & 18 & 1 & $5 \%$ \\
\hline Portland Seed Fund & 1 & 2 & $67 \%$ \\
\hline Promous Ventures & 2 & 0 & $0 \%$ \\
\hline Radius Ventures & 7 & 1 & $13 \%$ \\
\hline RedPoint & 17 & 0 & $0 \%$ \\
\hline Rockport Capital & 8 & 2 & $20 \%$ \\
\hline Roda Group & 3 & 0 & $0 \%$ \\
\hline RRE Ventures & 7 & 0 & $0 \%$ \\
\hline Rustic Canyon Partners & 4 & 0 & $0 \%$ \\
\hline Scale Venture Partners & 6 & 3 & $33 \%$ \\
\hline Scout Ventures & 3 & 0 & $0 \%$ \\
\hline Seneca Partners & 4 & 0 & $0 \%$ \\
\hline Shasta Ventures & 6 & 0 & $0 \%$ \\
\hline SJF Ventures & 5 & 1 & $17 \%$ \\
\hline Skyline Ventures & 4 & 0 & $0 \%$ \\
\hline Sofinnova Ventures & 13 & 2 & $13 \%$ \\
\hline Softbank Capital & 8 & 2 & $20 \%$ \\
\hline
\end{tabular}




\begin{tabular}{lccr} 
(Table 1 continued) & Men & Women & \%omen \\
\hline \multicolumn{1}{c}{ Venture Capital Firm } & 2 & 0 & $0 \%$ \\
Softtech VC & 8 & 0 & $0 \%$ \\
Spark Capital & 1 & 4 & $80 \%$ \\
StarVest Partners & 5 & 1 & $17 \%$ \\
Technology Partners & 5 & 0 & $0 \%$ \\
Tenaya Capital & 4 & 0 & $0 \%$ \\
The Westley Group & 7 & 1 & $13 \%$ \\
Trinity Ventures & 7 & 0 & $0 \%$ \\
True Ventures & 7 & 1 & $13 \%$ \\
U.S. Venture Partners & 7 & 1 & $13 \%$ \\
Union Square Ventures & 6 & 0 & $0 \%$ \\
Upfront Ventures & 14 & 2 & $13 \%$ \\
Vantage Point Capital Partners & 5 & 0 & $0 \%$ \\
VegasTech Fund & 11 & 1 & $8 \%$ \\
Venrock & 2 & 0 & $0 \%$ \\
Wavemaker & 4 & 0 & $0 \%$ \\
Webb Investment Network & 4 & 0 & $0 \%$ \\
Westley Group & 1 & 2 & $\mathbf{1 0 \%}$ \\
XG Ventures & $\mathbf{8 9 0}$ & & \\
Total & $\mathbf{9 4}$ & \\
\hline
\end{tabular}

Note: Data derived from individual venture capital websites searching for managing partners, directors, partners, and venture partners during August 2014.

\section{Women in Venture Capital}

In a 2011 survey conducted by the National Venture Capital Association (NVCA) found women accounted for $11 \%$ of directors and partners (Guglielmo, 2012). Women are not being hired as partners and directors at venture capital firms for a variety of reasons. Ebinger (2014) stated homophily. Males are less likely to hire a woman than a man because men do not know women well enough to hire. Another reason is women are usually not members of well-connected networks matching entrepreneurs with IVCs (Ebinger, 2014). Few women are CEOs of venture backed technology firms (Ebinger, 2014). The result is the pool of available females to become venture capitalists is small. Some women refrain from entering venture capital because of child, family, and house care issues (Ebinger, 2014).

Because women are increasingly gaining advanced education in finance, economics, in the STEM fields, and in senior management level positions, more women in venture capital might appear in the future (Ebinger, 2014). Approximately one third of master of business administration holders in the U.S. are women (Ebinger, 2014). Positions in startups and management in late-stage portfolio companies are being increasingly being filled by women, which should boost future female IVC numbers (Ebinger, 2014).

In the general finance industry, data suggested women who work on Wall Street decreased significantly relative to men. From 2001 to $2011,2.6 \%$ of female workers left the finance industry while men increased by $9.6 \%$ during the same timeframe (Bureau of Labor Statistics, 2013). The number of women aged 20 to 35 working in finance dropped by $16.5 \%$ while the number of men increase to $7.3 \%$ (Lietz, 2012). The highest losses at $21.8 \%$ were among women seeking entry-level positions in finance (Lietz, 2012). A NVCA 2011 survey found the number women decreased in the industry from $14 \%$ in 2008 to $11 \%$ in 2011 (Lietz, 2012).

Hiring directors and partners IVCs want candidates with expertise in the STEM fields, economics, and finance (Upbin, 2012). Women entering careers in venture capital have fewer primary network connections with decision makers in hiring positions (Brush et al., 2004). However, the venture capital industry is performance based and results driven, which should foster an egalitarian environment (Upbin, 2012). Successful IVCs regardless of gender must possess clear judgment and keen insight (Upbin, 2012). 


\section{STUDY PARAMETERS}

I contacted 385 venture capital directors and partners in the United States during July and August 2014. Out of 385 directors and partners, 20 partners and directors from 20 venture capital firms agreed to be interviewed. The purposive sampling was representative of IVCs in the United States (Orser, Elliott, \& Leck, 2011; Rezaei \& Bagheri, 2011). Purposive sampling was appropriate because IVCs are a specialized group of participants who possess experiences and specific knowledge to address the research question (Parlalis, 2011). Participant selection was based on three criteria: (a) partner or director level IVC with a United States-based firm, (b) was available to be contacted via telephone, and (c) was over the age of 18 . The research question guiding the study was what are the factors for the gender disparity among directors and partners at independent venture capital firms in the United States.

Mason (2010) asserted that 15 participants was the smallest acceptable sample for a qualitative study. Hanson, Balmer, and Giardino (2011) confirmed that 10 to 20 participants were sufficient to confirm themes. Orser et al. (2011) conducted a qualitative study with 15 interviewees. Participants were derived from venture capital firm websites. Websites were located from online searches of directories of IVC firms.

I e-mailed an introduction letter to potential interviewees asking whether the participant was interested in participating in the study. Each participant was a partner or director in the IVC firm. Participants were offered a gift card as remuneration for participating in the study. All interviews were conducted on the telephone. Cachia and Millward (2011) argued that utilizing the telephone for qualitative data collection was a viable option. The participants in the study responded to semistructured focused interviews asked in a conversational manner over the telephone (Yin, 2009). I utilized semistructured interviews to recognize broad themes and to direct the topic conversation in a systematic and consistent manner designed to elicit elaborate responses from participants (Qu \& Dumay, 2011). Interview questions used in the study were:

- Industry wide, women account for approximately $10 \%$ of partners and directors. What are the reasons and factors you believe more women are not hired as partners or directors?

- What specific skill sets you believe women bring to the table that men do not?

- What solutions would you propose to close the gap between women and men participation as managing partners and directors?

\section{FACTORS CONTRIBUTING TO GENDER DISPARITY}

Four factors contribute to gender disparity in the IVC industry. The factors are limited mentoring opportunities for females, lack of executive management experience of women, female exclusion from niche networks, and male and female IVCs unwilling to address the gender disparity issue. Participants mentioned limited mentoring opportunities most frequently.

\section{Limited Mentoring Opportunities}

One significant factor why women are not hired commensurate to men in venture capital is the limited mentoring opportunities (Evans, 2014). Many male IVCs do not want to mentor women. One reason could be homophily. Another reason cited by participants was women who came from the apprentice track or as a retired executive did not have the essential experience as an entrepreneur and would likely be an unsuccessful IVC. Because of a lack of real-world entrepreneurial experience, some women are believed by IVCs to be limited in contributing to the success of nascent entrepreneurs. Participants declared IVCs were too busy with their portfolios to mentor a female IVC. Some IVCs did not see a high return on investment in time and effort mentoring a female. Other participants argued mentoring is time consuming taking away precious resources that could be used in developing the next big portfolio firm. The concern with several participants was female IVCs would work in industry for a couple of years and then quit to start a family. 


\section{Lack of Management Experience}

Venture capital is a niche sector within finance. Participants cited hiring managers at IVC firms want seasoned executives with management experience with start-ups, in targeted technology sectors, and with professional degrees from top business schools in the United States. Few women establish STEM-based start-ups, and even fewer lack executive management experience. According to several participants, 2/3 of IVCs were former executives and 1/3 earned advanced degrees with no tangible management experience before entering venture capital. The primary reason partners and directors want to hire seasoned executives is the challenge to get funders from pension funds, high net worth individuals, insurance companies, and other institutional investors to give unseasoned IVCs millions of dollars to invest in an early stage portfolio firm.

\section{Women Excluded from Niche Networks}

IVCs are reliant on formal and informal networks to locate nascent entrepreneurs and to recruit IVC personnel. Participants mentioned women often lack access to IVC networks, which are created and maintained by men. At the same time, very few director and partner positions are available per year. Female participants suggested women should support and work together rather than competing and demoralizing each other. Participants argued that because women have difficulty accessing established networks, women should create their own network complimenting but not competing with established male dominated IVC networks.

\section{Unwilling to Address Gender Disparity}

One conspicuous factor noted in the study was $95 \%$ of men and women directors and partners were unwilling to discuss gender disparity in the industry. Several factors exist why IVCs were reluctant to discuss gender disparity. One factor is the nature of the IVC industry.

IVCs are an elite group of highly educated, experienced, and skilled individuals who work in small "clubby" environments where most know and cooperate with each other (Lietz, 2012). Most IVCs have 10+ years experience in venture capital (Lietz, 2012). Because nearly everyone knows everyone else, many participants appeared to be fearful discussing gender disparity. Rejection responses to participation in the study mentioned the firm did not have a gender disparity issue, the organization is blind to gender differences, and the firm hires the best candidate. However, none of the rejection respondents firms had female partners or directors according to their website. Often male IVCs would forward study participation requests to non-partner or non-director female members of the firm who did not respond to the study. The females who were partners and were invited to participate in the study often refused to do so.

IVCs who participated in the study were asked why they believed partners and directors would be reticent to participate. Participants mentioned many IVCs were afraid that talking about gender disparity might jeopardize their positions within the firm. Other IVCs did not want to disrespect the fund. Possibly the chief reason is the potential fall out of the lawsuit filed by Pao against Kleiner Perkins Caufield \& Byers (KPCB) in May 2012 (Thomas, 2012).

Pao filed a lawsuit against KPCB after several partners attempted to silence Pao's claims of being sexually harassed. Pao also claimed that women were regularly left out of meetings with male partners, and Pao was unfairly passed over for promotions because of her gender and refusing to give into sexual harassment (Ebinger, 2014). Many IVCs appeared unsure how to discuss and deal with gender disparity within their own firms until the lawsuit has been adjudicated.

\section{IMPLICATIONS}

More women participation in venture capital is needed to create opportunities for first-degree network connections between male and female IVCs and women entrepreneurs (Brush et al., 2004). Greater numbers of qualified female IVCs would provide more opportunities for women-led enterprises to gain access to capital and build wealth creation, create more jobs, and enhance the economic health of the United States (Brush et al., 2004). 
Merino (2013) noted boards comprised of at least 33\% women consistently outperform market trends and generate significant positive financial returns. In the marketplace, women often know better than men what women want (Brush et al., 2004). The venture capital industry needs more women to help all entrepreneurs meet the market demands of women.

\section{RECOMMENDATIONS}

With women representing approximately $10 \%$ of IVCs in the U.S., partners and directors need to increase the number of women partners and directors by recruiting, mentoring, and promoting qualified females from STEM fields. Male partners and directors need to emphasize through extensive marketing efforts the openness of the industry to female entrepreneurial executives. Institutional and high net worth funders and limited partners should demand (a) greater number of qualified and experienced females receive early-stage funding for ventures, (b) increased hiring of women from the three tracks, and (c) insist on more qualified women sitting on corporate boards.

Venture capital trade organizations should create media awareness of the lack of women participation as directors and partners in the industry (Brush, Greene, Balachandra, \& Davis, 2014). Rather than not addressing or acting as gender disparity does not exist in venture capital, IVCs should reduce bias toward women and welcome qualified women in decision-making roles. Qualified women entrepreneurs and potential female IVCs should have access to mentoring, investment, and networking opportunities across all industry sectors in addition to STEM fields.

\section{CONCLUSION}

In this paper, I provided a review of the literature related to the IVC industry in terms of gender disparity and women in venture capital. The study parameters where provided. In the research study, I interviewed 20 IVCs in the United States who provided four factors contributing to why approximately $10 \%$ of IVC partners and directors are female. The implications and recommendations for increasing the number of female participation in venture capital were presented. The noteworthy takeaway is greater numbers of qualified female partners and directors need to be hired in the venture capital industry for the United States to maintain an economic and entrepreneurial competitive advantage.

\section{AUTHOR INFORMATION}

David Blum is an adjunct faculty mentor in the School of Business Management and Technology at Northcentral University. Dr. Blum holds a Bachelor's Degree in History from Bellarmine University, a Master of Business Administration (MBA) in Sustainable Business from Marylhurst University, and a Doctor of Business Administration (DBA) from Walden University. Email: david@greenwolfconsulting.com

\section{REFERENCES}

Baron, R. A., \& Markman, G. D. (2000). Beyond social capital: How social skills can enhance entrepreneurs' success. The Academy of Management Executive, 14, 106-116. doi:10.5465/AME.2000.2909843

Blum, D. A. (2014). A venture capital handbook: Best practice strategies for investing in microalgae biodiesel. Huntsville, AL: Emerson Street Press.

Brush, C. G., Carter, N. M., Gatewood, E. J., Greene, P. G., \& Hart, M. M. (2004). Gatekeepers of venture growth: The role and participation of women in the venture capital industry. Retrieved from http://www.issuelab.org/resource/gatekeepers_of_venture_growth_a_diana_project_report_on_the_role_an d_participation_of_women_in_the_venture_capital_industry

Brush, C. G., Greene, P. G., Balachandra, L., \& Davis, A. E. (2014). Venture capital industry should be re-examined based on gender and geographical investment preferences. Diana report women entrepreneurs 2014:

Bridging the gender gap in venture capital. Retrieved from http://www.babson.edu/Academics/centers/blank-center/global-research/diana/Documents/diana-projectexecutive-summary-2014.pdf

Bureau of Labor Statistics. (2013). Women in the workforce. Retrieved from http://www.bls.gov/home.htm 
Cachia, M., \& Millward, L. (2011). The telephone medium and semistructured interviews: A complementary fit. Qualitative Research in Organizations and Management: An International Journal, 6, 265-277. doi:10.1108/17465641111188420

Ding, W., Murray, F., \& Stuart, T. (2013). From bench to board: Gender differences in university scientists' participation in corporate scientific advisory boards. Academy of Management Journal, 56, 1443-1464. doi:10.5465/amj.2011.0020

Dotzler, F. (2001). What do venture capitalists really do, and where do they learn to do it? The Journal of Private Equity, 5(1), 6-12. doi:10.3905/jpe.2001.319997

Ebinger, C. (2014). The state of female investing. Retrieved from https://www.kabbage.com/blog/women-venturecapital\#

Evans, D.P. (2014). Aspiring to leadership... A woman's world? Procedia - Social and Behavioral Sciences, 148, 543-550 doi:10.1016/j.sbspro.2014.07.077

Fernandez-Mateo, I., \& King, Z. (2011). Anticipatory Sorting and Gender Segregation in Temporary Employment. Management Science, 57, 989-1008. doi:10.1287/mnsc.1110.1333

Fiske, S. T., Cuddy, A., Glick, P., \& Xu, J. (2002). A model of (often mixed) stereotype content: Competence and warmth respectively follow from perceived status and competition. Journal of Personality and Social Psychology, 82, 878-902. doi:10.1037//0022-3514.82.6.878

Gatewood, E. J., Brush, C. G., Carter, N. M., Greene, P. G., \& Hart, M. M. (2009). Diana: A symbol of women entrepreneurs' hunt for knowledge, money, and the rewards of entrepreneurship. Small Business Economics, 32, 129-144. doi:10.1007/s11187-008-9152-8

Gorman, E., \& Kmec, J. (2009). Hierarchical rank and women's organizational mobility:

Glass ceilings in corporate law firms. American Journal of Sociology, 114, 1428-1474. Retrieved from http://www.press.uchicago.edu/ucp/journals/journal/ajs.html

Guglielmo, C. (2012). Silicon Valley venture capital firms say they welcome more women -- If only they could find some. Retrieved from http://www.forbes.com/sites/connieguglielmo/2012/06/07/silicon-valleyventure-capital-firms-say-they-welcome-more-women/

Hanson, J. L., Balmer, D. F., \& Giardino, A. P. (2011). Qualitative research methods for medical educators. Academic Pediatrics, 11, 375-386. doi:10.1016/j.acap.2011.05.001

Jackson, W. E., Bates, T., \& Bradford, W. D. (2012). Does venture capitalist activism improve investment performance? Journal of Business Venturing, 27, 342-354. doi:10.1016/j.jbusvent.2011.02.003

Lietz, N.G. (2012). Cloistered in the pink ghetto: Women in private equity, real estate, and venture capital. Retrieved from http://68.234.80.80/Investments/partner_resources/CloisteredPinkGhetto.pdf

Li, Y., \& Zahra, S. A. (2012). Formal institutions, culture, and venture capital activity: A cross-country analysis. Journal of Business Venturing, 27, 95-111. doi:10.1016/j.jbusvent.2010.06.003

Mason, M. (2010). Sample size and saturation in PhD studies using qualitative interviews. Forum: Qualitative Social Research, 11(3), 1-19. Retrieved from http://www.qualitative-research.net/index.php/fqs

Merino, F. (2013). What women want: Do we need more female VCs? Less than 10\% of VCs are women; do we need more? Retrieved from http://vator.tv/news/2013-03-18-what-women-want-do-we-need-more-femalevcs

Nelson, T., Maxfield, S., \& Kolb, D. (2009). Women entrepreneurs and venture capital: Managing the shadow negotiation. International Journal of Gender and Entrepreneurship, 1, 57-56. Retrieved from http://www.emeraldinsight.com/loi/ijge

Olsson, N. O. E., Frydenberg, S., Jakobsen, E. W., \& Jessen, S. A. (2010). In search of project substance: How do private investors evaluate projects? International Journal of Managing Projects in Business, 3, $257-274$. doi:10.1108/17538371011036572

Orser, B. J., Elliott, C., \& Leck, J. (2011). Feminist attributes and entrepreneurial identity. Gender in Management: An International Journal, 26, 561-589. doi:10.1108/17542411111183884

Parlalis, S. K. (2011). Management of organisational changes in a case of de-institutionalisation. Journal of Health Organization and Management, 25, 355-384. doi:10.1108/14777261111155010

Qu, S. Q., \& Dumay, J. (2011). The qualitative research interview. Qualitative Researchin Accounting \& Management, 8, 238-264. doi:10.1108/11766091111162070

Rezaei, M., \& Bagheri, A. (2011). Comparative analysis of characteristics of adopters and non adopters of artificial insemination in Ardabil Province of Iran. Emirates Journal of Food Agriculture, 23, 466-472. Retrieved fromhttp://ejfa.info 
Ridgeway, C. L., \& Correll, S. J. (2004). Unpacking the gender system: A theoretical perspective on gender beliefs and social relations. Gender \& Society, 18, 510-531. doi:10.1177/0891243204265269

Schertler, A., \& Tykvova, T. (2011). Venture capital and internationalization. International Business Review, 20, 423-439. doi:10.1016/j.ibusrev.2010.07.009

Skaggs, S., Stainback, K., \& Duncan, P. (2012). Shaking things up or business as usual? The influence of female corporate executives and board of directors on women's managerial representation. Social Science Research, 41, 936-948. doi:10.1016/j.ssresearch.2012.01.006

Smart, G. H., Payne, S. N., \& Yuzaki, H. (2000). What makes a successful venture capitalist? The Journal of Private Equity, 3(4), 7-29. doi:10.3905/jpe.2000.319948

Spence, J. T., \& Buckner, C. E. (2000). Instrumental and expressive traits, trait stereotypes, and sexist attitudes: What do they signify? Psychology of Women Quarterly, 24, 44-62. doi:10.1111/j.14716402.2000.tb01021.x

Thomas, O. (2012). Meet all the players in the Kleiner sex scandal that's rocking Silicon Valley. Retrieved from Retrieved from http://www.businessinsider.com/kleiner-perkins-ellen-pao-lawsuit-sex-scandal-siliconvalley-2012-6?op=1\#ixzz3Ik39upb9

Upbin, B. (2012). Venture capital is a great place for women if they'd give it a chance. Retrieved fromhttp://www.forbes.com/sites/ciocentral/2012/07/26/venture-capital-is-a-great-place-for-women-iftheydgive-it-a-chance/

Yin, R. K. (2009). Case study research: Design and methods (4th ed.). Thousand Oaks, CA: Sage Publications, Inc.

Zhang, T. X., Aksu, B. P., \& Wang, H. (2012). Conflicts of interest in venture capital-backed IPO firms. Journal of International Finance \& Economics, 12(2), 50-59. Retrieved from http://www.iabe.org/domains/iabe/journal.aspx?journalid=11 